Act, in order that if any of these should disclose any risk of the destruction of sites or objects of scientific interest, representations may be made on behalf of the Association to the planning authorities and to the Ministry. In addition to natural features, or possibly buildings, which may be worthy of preservation on scientific grounds alone, it is clear that there must be many areas worthy of protection on grounds of amenity, and at the same time of sufficient scientific interest, whether geological, botanical or otherwise, to justify adducing arguments from the side of science in their favour. The first step taken by the Council of the Association was to communicate with all the local societies in correspondence with the Association, inviting their attention to the subject of planning and asking for information on any instances in which the Association might usefully take action : only a few have as yet come to hand. The whole subject will come under consideration at the Norwich meeting of the Association, when it will be dealt with by Prof. P. G. H. Boswell in an address as chairman of the Conference of Delegates of Corresponding Societies. Meanwhile the Council has appointed a panel of some sixty prominent members representative of geology, geography, botany and zoology, any of whom may be called upon for advice in connexion with proposals for preservation, and all of whom have been asked to bring to the notice of the officers any examples which may have come under their personal notice.

\section{Roman Villa near Lydney}

A NEw Roman villa on the River Severn near Wollaston, between Lydney and Chepstow, of which the discovery and partial exploration is described in The Times of March 8, illustrates the perennial character of the human response to an enduring need. A fire-platform and lighthouse in alignment mark the channel through the Guskar Rocks guarding the creek, on which the villa is situated, in a manner which might stand in a modern sailing direction. Before the examination of the site the existence of the creek, which had silted up, was indicated only by a stream in a depression; but evidently it must have been, with Lydney harbour, a port of call of importance, probably in relation to the iron-workings of Ariconium (Weston-under-Penyard) to the north. In any event, the villa with its sea-frontage was not only the centre of a wide settlement, still unexplored, but it is remarkable also for the unusual amount of iron it has yielded among its relies. The earlier villa, upon which a second was superimposed, was erected about A.D. 130 in the reign of Hadrian. It stood about 250 yards from the shore. It was of considerable size and contained nine rooms and a corridor and had a bath system along the sea front. One hundred and seventy years later it was destroyed, possibly, it is thought, by an Irish raid. After a lapse of twenty years, the second, a smaller building, was erected. It contained only four rooms, but it also had a bath system. This villa lasted for about a century. The details of the buildings and the associated relies have provided a number of noteworthy features, and the further examination of the site, which depends, as usual, upon funds being raised, will undoubtedly well repay the expenditure of time and money.

\section{Irish Folk-lore}

THE appointment by the Irish Free State of a Commission on Irish folk-lore is an extension of the active interest already shown by the authorities in the antiquities and history of Ireland that will be welcomed by all students of her traditions and ancient culture. The Commission is to be comprehensive in scope. It will arrange for the collection, collation and cataloguing of both oral and written folk-lore material, and also, if thought desirable, for the publication of such material. The scheme for collection which has been drawn up includes provision for a body of collectors who will travel through the country for the purpose of taking down by means of recording machines not only tales and songs, but also, among the older members of the community, their recollections of life in the country-side in their young days. Subject to the approval of Dail Eireann, a sum not exceeding $£ 3,250$ a year, for a period of five years, will be devoted to the work of the Commission. Although Ireland, in comparison with other parts of the British Isles, has not been badly served in the matter of attention from the collector of local lore and legends, it has always been known that extensive tracts of tradition and custom remained untouched; and notwithstanding the sophistication which has affected Ireland in common with other countries of recent years, the remoter districts still retain much of their primitive character and tradition. In addition to its work of collection, the Commission's activities will afford an opportunity for that systematic treatment of the material for which adequate opportunity has not hitherto been available, but which in dealing with conditions in Ireland is highly desirable.

\section{British Museum Acquisitions}

Among the notes on recent acquisitions by the British Museum in the British Museum Quarterly, 9, No. 3, particulars are given of sources from which came part of the sum required to make up the initial payment for the Eumorfopoulos collection of Chinese and Far Eastern art, and progress is reported in the allocation of the collection to Bloomsbury and South Kensington. A contribution of $£ 5,000$ was received from the National Art Collections Fund, $£ 5,000$ from Sir Percival David and $£ 1,000$ from the Universities' China Committee in London. The bequest to the British Museum and the Victoria and Albert Museum of three quarters of the residue of the estate of the late J. R. Vallentin for the purchase of works of art for the two museums was also allotted to this use. It is stated that the collection is so large that it will be possible to place a certain number of pieces on loan in some of the leading provincial museums. When, however, the scheme for a Museum of Oriental Art comes into being, it is intended to recall these loans, and the whole collection will be brought together again to form an important part of what, it is hoped, will be the finest museum of oriental art 
in existence. Parts of the collection already have been, or are in course of being, described, but accounts of special classes of exhibits are to be prepared and published from time to time. Among other notes in this issue of an interesting publication which is not so widely known as it deserves, is an account of the fragments of the unknown gospel acquired last summer, to which Mr. H. L. Bell has recently directed attention in The Times, and descriptions with illustrations of an Egyptian wax figure which, if it be, as is thought, a model for making moulds for casting bronze figures, is indeed rare, and some unique objects of a varied nature from Roman London.

\section{Empire Cotton Growing Corporation}

Ar a meeting of the Administrative Council of the Empire Cotton Growing Corporation held in Manchester on February 7, the resignation was received of Mr. Milligan, who has been the Corporation's senior representative in Africa since 1924. During this time he has travelled constantly about South Africa and visited in addition the Corporation's staff in Swaziland and Rhodesia. He has been succeeded by Mr. Parnell, who has long been associated with the Corporation's work in South Africa. The Council received the report of Mr. May, assistant secretary of the Corporation, upon a tour he had recently made in East and South Africa, particularly with reference to developments in Tanganyika Territory. At many places in this territory, the Corporation's assistance will be used towards developing an interesting scheme, evolved by the Agricultural Department, for native holdings on which cotton will be grown in a system of mixed farming. Each family will be given the freehold of their holding, which will consist of 20 acres. Of these, 10 acres will be reserved for cattle grazing, and the remainder for the dwelling site and land for the cultivation of cotton and other crops. The natives will also be given instruction in the preparation and use of farmyard manure.

THe Mwanza area of Lake Province has hitherto produced about half the cotton grown in Tanganyika. The organisation of its seed supply is therefore a matter of importance, and with the help that is now being given by the Corporation it is hoped to put this on a satisfactory basis. The selection of the best strains will be carried out at the Experiment Station at Ukiriguru; these will then be multiplied in the special area that is being provided for the purpose, just across the arm of Lake Victoria known as Smith Sound. The seed from this area will be bulked on an island in the Lake, which makes an admirable isolated area where admixture of the strains can be prevented. The bulked seed will then be distributed in the following season throughout the Lake Province.

\section{Forest Research in the Malay States}

THE annual report of the Forest Research Branch, 1933 , is issued with the "Report on Forest Administration for the year 1933 of the Federated Malay States" (a Supplement of the F.M.S. Government Gazette, June 15, 1934. F.M.S. Government Press). Research, under which is included education, has made con. siderable progress in the Forest Department of the Federated Malay States, A Forest School has been started much on the lines of the Rangers' School at Dehra Dun, India, which has nearly half a century of good work behind it. The practical courses of the Malay School during the year under view included a forest reconnaissance in mountainous jungle in the State of Perak; it served the excellent purpose, among others, of acquainting the students with commercial tree forms not normally encountered in the lowland forests. An area of 2,400 acres of this hill forest in the Bubu reserve was explored and the enumeration work was conducted on more intensive lines than hitherto, both as regards composition of the crop and the possibility of commercial exploitation. This appears an excellent departure and the experience thus gained should be invaluable to all, whilst the work achieved will be of practical value. Research work is being carried on in sylviculture, where some interesting research work is being achieved, botanical, wood technology, timber testing, wood preservation and forest economy generally; while zoological, chemical and meteorological problems are being studied.

\section{The National Herbarium at Melbourne}

Thanks to the generosity of Sir MacPherson Robertson, a new building has just been completed in Melbourne for the housing of the National Herbarium collections, and the transfer of material is in progress. The building is a block, approximately $100 \mathrm{ft}$. by $80 \mathrm{ft}$., containing two floors. On the upper floor provision is made for the collections (numbering some 1,500,000 sheets) and for a library of more than 10,000 volumes. On the lower floor are a museum of economic botany, a laboratory, a lecture hall and the administrative offices. The construction is fire-proof throughout; all cabinets are of steel and the main door is guarded by fire-proof devices operating automatically when the temperature reaches a certain point. The collection was commenced about 1856 by the late Baron von Mueller, and it is intended to preserve the existing division into two sections (i) Australian and (ii) extra-Australian. The former is very complete and contains a number of type specimens. The room allotted to it is $60 \mathrm{ft}$. by $35 \mathrm{ft}$., allowing for 30 per cent expansion, or 55 per cent if further cabinets be installed. The extra-Australian section, which is already extensive and is continually growing by exchanges, will be housed in a room $80 \mathrm{ft}$. by $35 \mathrm{ft}$.

\section{Sounds made by Fishes in the East Indies}

In NATURE of November 17 (p. 769), we quoted an interesting account of sounds heard in the East Indies by Capt. P. Jansen. We have received a letter from Dr. J. D. F. Hardenberg, of the Laboratory for Investigation of the Sea, Batavia, with reference to this note. He states that the comparison of these noises with the sounds made by foghoms is quite correct. They remind one also of the sounds made by motor traffic on a busy thoroughfare when heard at a distance of about a hundred yards. The noises, however, do not proceed from the earth, but are 